\title{
口腔顎顔面領域の血管腫に対するエタノール局注療法の経験
}

\author{
北川善政・橋本賢二・片山貴之・山口万枝 \\ 佐塚太一郎・水野明夫*・高橋元一郎**

\section{Direct ethanol injection therapy for hemangiomas in the oral and maxillofacial region} \\ Yoshimasa Kitagawa - Kenji Hashimoto - Takayuki Katayama \\ Kazue Yamaguchi - Taichiro Sazuka - Akio Mizuno* \\ Motoichiro - TAKAHASHI**
}

\begin{abstract}
Many treatments have been recommended for the management of hemangiomas. However, postoperative esthetics and function of the organs are often the problems for lesions in the oral and maxillofacial region. Absolute ethanol is an effective agent in the treatment of hemagiomas which may not be resectable.

Two patients with hemangiomas in the oral and maxillofacial region which were treated by direct ethanol injection are described. Case 1 was an 82 -year-old female with a cavernous hemangioma of the mouthfloor. Case 2 was a 64 -year-old female with a venous angioma of the cheek. Both patients were admitted to our hospital because of gross swelling.

However, resection of these extensive hemangiomas would most likely lead to gross disfigurement and dysfunction. We therefore tried direct ethanol injection therapy. Initially the lesions demonstrated a reactive inflammatory edema which was followed by slow resolution over several days with subsequent mild fibrosis. The lesion in case 1 required 4 ethanol injections $(2 \mathrm{ml} \times 4)$ during 4 months, and the lesion in case 2 was controlled solely by a single injection $(5 \mathrm{ml})$. Direct ethanol injection therapy provided the greatest opportunity for preserving the surrounding normal tissue and obtaining improved cosmetic and functional results.
\end{abstract}

Key words: absolute ethanol (純エタノール), direct injection therapy（局注療法）, hemangioma（血管腫）

緒言

口腔顎顔面領域に発生した血管腫の治療には従来より 種々の方法が試みられているが, 腫瘍に対する縮小, 消
失効果と併せて, 局所の機能的，審美的な面も考慮しな ければならない。われわれは肝癌の治療法として最近注 目されている経皮的エタノール局所注入療法 ${ }^{1)}$ (Percutaneous Ethanol Injection Therapy: PEIT) に着目し, 口腔外科領域の血管腫治療への応用を試みた。 口底, 顔
浜松医科大学医学部歯科口腔外科学数室

（主任：橋本賢二教授）

* 長崎大学歯学部第 1 口腔外科学教室 （主任：水野明夫教授）

**浜松医科大学医学部放射線医学教室 （主任：金子昌生教授）

Department of Dentistry and Oral and Maxillofacial Surgery, Hamamatsu University School of Medicine (Chief : Prof. Kenji Hashimoto)

* The First Department of Oral and Maxillofacial Surgery, Nagasaki University School of Dentistry (Chief: Prof. Akio Mizuno)

** Department of Radiology, Hamamatsu University School of Medicine (Chief: Prof. Masao Kaneko)

受付日：平成 4 年12月20日 


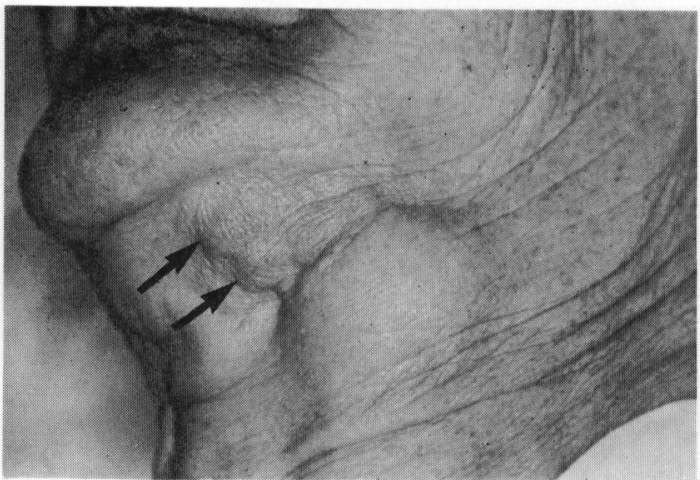

写真 1 症例 1

矢印：暗紫色の軟らかい腫脹。

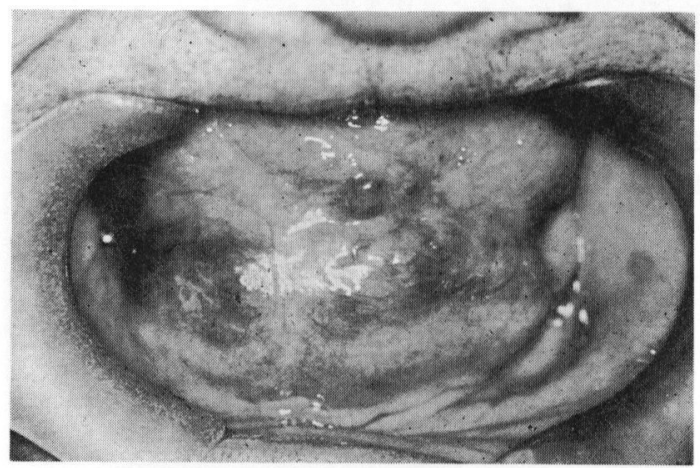

写真 2 症例 1 口腔内写真

二重舌を呈している.

面の比較的大きな血管腫に対して, 純エタノールの局注 療法を行い，機能・審美性を損うことなく腫瘍が消失 し, 非常に満足のいく結果が得られたので, その概要を 報告する。

症例

\section{症例 1}

患 者: 82歳 女性.

初 診: 平成 2 年10月口日。

主 訴：口底の腫脹, 義歯不適合.

家族歴：特記事項なし。

既往歴 : 40歳頃より躁蓋病.

現病歴: 平成 2 年 9 月より躁眦病で他病院に入院中, 1 か月半前より口底正中部の腫脹に気つうき, 義歯不適合 となったため, 当科紹介され来院した.

現症

口腔外所見 : 左顎下部に直径 $10 \mathrm{~mm}$ と $15 \mathrm{~mm}$ の被圧

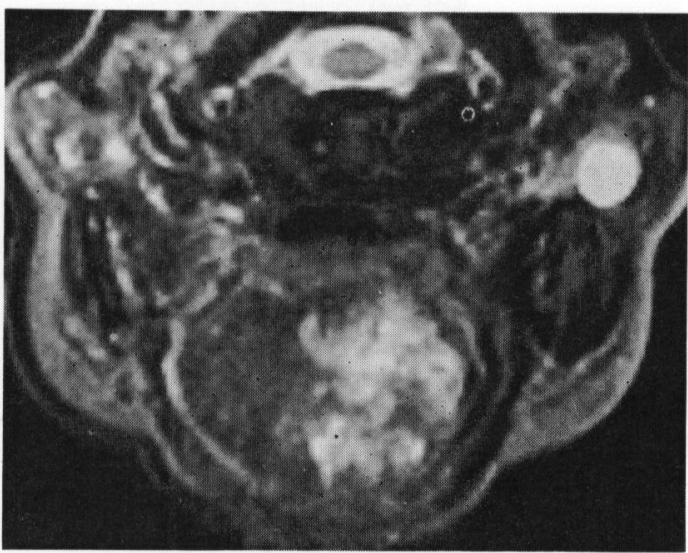

写真 3 症例 1 MRI 像 (T2 強調画像)

口底から左頞部体表面付近に達する不均一不整形の 高信号領域が認められた。

縮性の暗紫色の軟らかい腫脹が認められ, 口腔内の病変 と連続しているように思われた（写真１）。 また，左頸部 に直径 $50 \mathrm{~mm}$ の弾性硬, 無痛性の腫脹が認められたが, これは幼少時より存在していたとのことであった。

口腔内所見：舌下，口底部に $40 \times 25 \times 15 \mathrm{~mm}$ の境界 不明瞭，暗紫色の軟らかい腫瘤が認められた，舌は前方 突出不能で, 二重舌状を呈していた（写真 2 ）。腫脹は無 痛性, 被圧縮性で波動は触れなかった。

臨床検査所見：特に異常所見は認められなかった。

$\mathbf{X}$ 線所見：パノラマX線写真では, 患者は無歯顎で, 直径 $2 \sim 7 \mathrm{~mm}$ 大の静脈石と思われる多数の石灰化物が 認められた。

処置および経過：平成 2 年 11 月曰日入院し, MRI 検 查，血管造影を施行した。

MRI 所見：T2 強調横断像では, 口底から左頸部体 表面付近に達する不均一不整形の高信号領域が認められ た。この領域はわずかに造影され，辺緑が不明瞭であ ることや信号強度が不均一なことより，通常認められ る血管腫とはやや異なるように思われた。動静脈奇形 (AVM) を思わせる流入動脈や灌流静脈は認められず, また, 静脈瘤のような所見でもなく，他の血管奇形が考 えられた(写真了).

血管造影所見：右大腿動脈より Seldinger 法による血 管造影を施行した，左外頸動脈からのデジタルサプトラ クションアンギオグラフィー (DSA) 像では, これらの 末梢に明らかな 血管の豊富な 病変は認められなかった (写真 4 ). 次に, 左舌動脈の超選択的血管造影を施行し たが, 動脈相, 静脈相とも, 明らかな流入動脈や灌流静 脈は認められす゚, AVM は否定された。右側もほぼ同様 の所見であった。 そこで, 左右の舌動脈をスポンゼルの 小片により動脈塞栓術を施行した後, 再び血管造影を施 


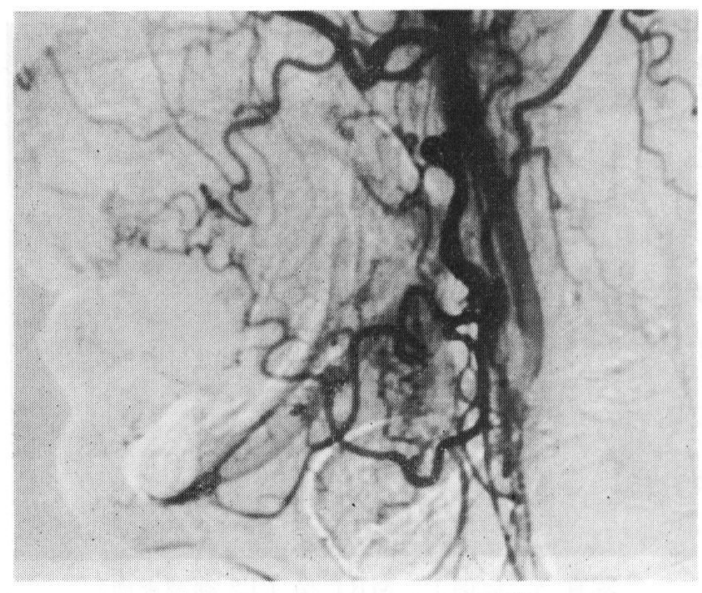

写真 4 症例 1 血管造影像

左外頸動脈からのデジタルサブトラクションアンギ オグラフィー (DSA) 像では, 明らかな血管の豊富 な病変は認められない。

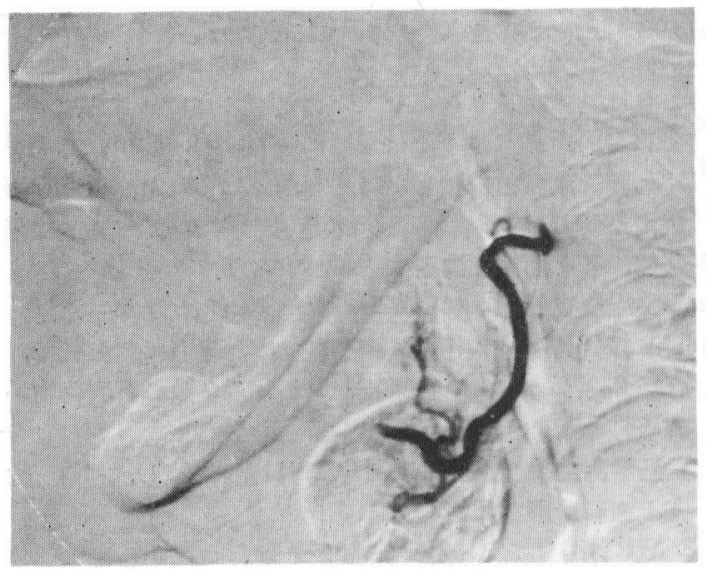

写真 5 症例 1 血管造影像

左右舌動脈塞栓術後の DSA 像 : 良好飞塞栓されて いる.

行し, 良好に塞栓されていることを確認した（写真 5). 次に口底の血管病変に $23 \mathrm{G}$ 針で直接穿刺したところ, 少 量の血液の逆流をみたので, それを吸引後, 直接造影剂 を注入した (写真 6 )。これらの所見より, 海綿状血管腫 々診断されたので, 局所麻酔下に $99.5 \%$ エタノール（以 下エタノール) を左右に $1 \mathrm{~m} l$ ずつ注入した．穿刺部位 は約10分間圧迫を行い，出血は認められなかった。注入 後局所の疼痛を訴えたが，鎮痛剂は不要であった。エタ ノール注入 24 時間後には, 口底部は著明に浮腫性飞腫脤 し, 発赤が認められた。 2 日間38度台の発熱が認められ たが，3 日目には平熱㞍った。气の後, 腫镺は消退せ ず，11月曰日，同部に $23 \mathrm{G}$ 針にて穿刺したところ，約 1

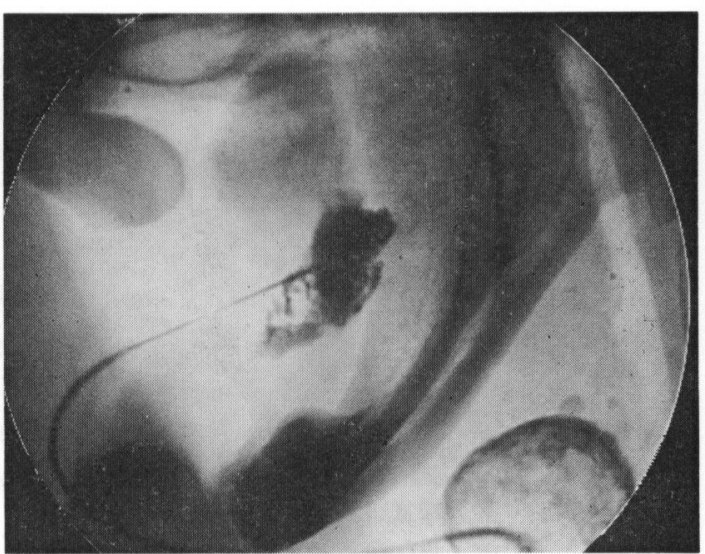

写真 6 症例 1

口底の血管病変に直接造影剤を局所注入し造影した。

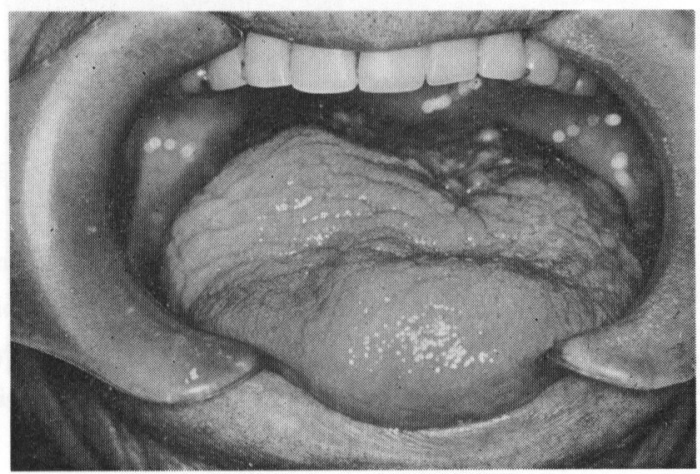

写真 7 症例 1

エタノール局注療法後義茵装着可能になった。

$\mathrm{m} l$ の血液が吸引できたので, 左右に各の $1 \mathrm{~m} l$ エタノー 儿を局注した。その後, 外来にて同年 12 月曰日と平成 3 年 3 月曰日に同様に左右に各 $1 \mathrm{ml}$ のエタノールを局注 した。合計 4 回のエタノール局注で, 腫脹は著明に縮小 し,わずかな線維性の硬結を残して完全に消失した。舌 は突出可能となり義歯が装着できるようになった（写真 7 ).

\section{症例 2}

患 者: 64歳 女性.

主 訴：左頓部～側頭部の腫脹。

初 診: 昭和 57 年 2 月曰日.

家族歴・既往歴：特記事項なし。

現病歴 : 新生児期より左煩部に腫脹が認められ，1歳 時, 穿刺吸引により, 腫脹消失。その後, 腫脹, 穿刺, 吸引, 消退を十数回繰り返していた. 平成 2 年 12 月曰日, 当科に入院した.

現 症：左側側頭部と頓部に波動を伴う腫脹が認めら 


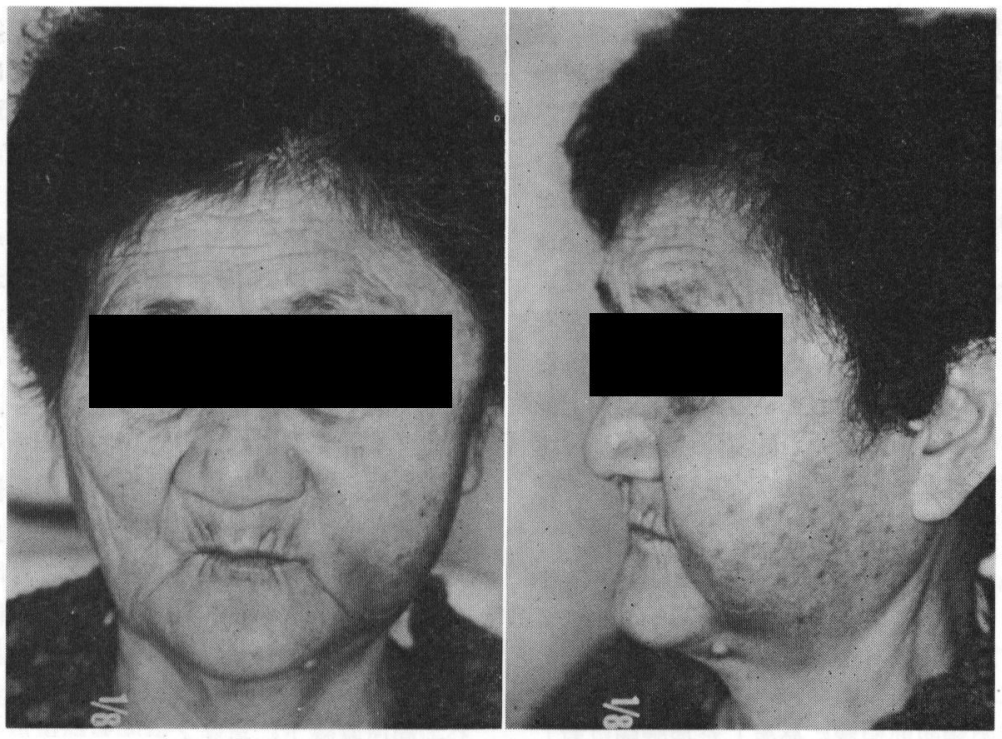

写真 8 症例 2 顔貌写真

左側側頭部と頓部に波動を伴 万腫脹が認められた。

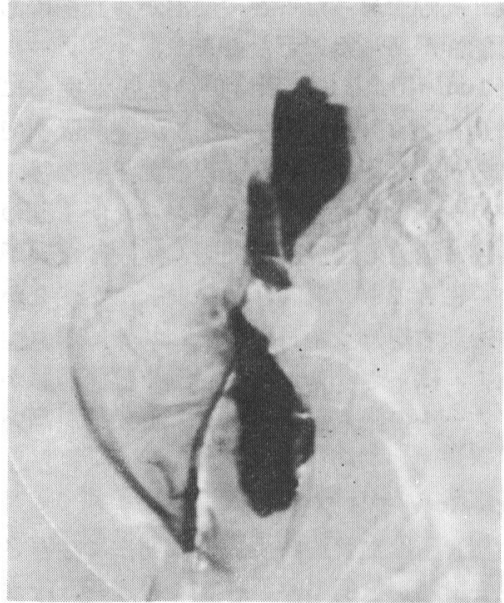

写真 9 症例 2

直接造影剤を注入し造影された。左 耳介前方と類部の異常血管腔は連続 して扣り, 静脈性のうっ㴖が認めら れた。

れた。圧縮性はなく，色調は正常皮膚色であった。側貌 写真では，著明に煩部が腫脹していた（写真 8 ）。

X線所見：特に異常所見は認められなかった。

臨床検査所見：特に異常所見は認められなかった。

処置および経過：平成 3 年12月日日, 右大腿動脈より Seldinger 法による血管造影を施行した。左外頸動脈か らの DSA では, 動脈相での腫瘍濃染や静脈相での造影

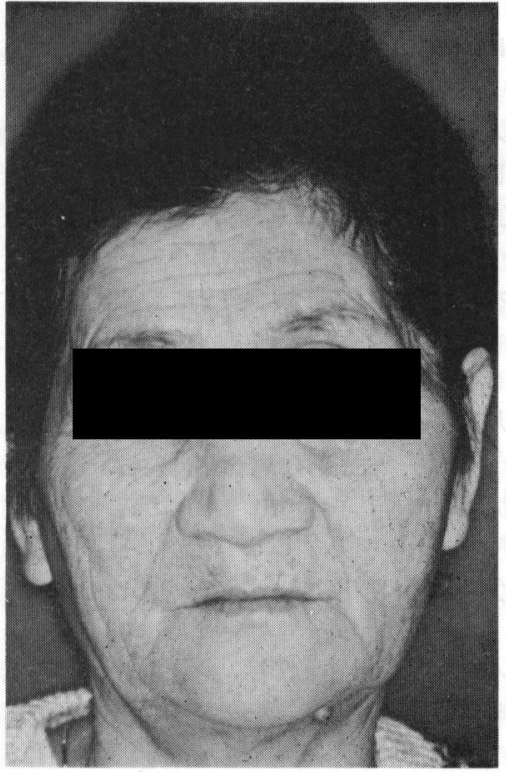

写真 10 症例 2

エタノール局注療法後, 顔貌は左右 対称で審美的にも満足のいく結果が 得られた。

剂貯留像は認められなかった。動脈造影では造影され ず，20G 針にて直接穿刺により静脈血様穿刺液 $17 \mathrm{~m} l$ を 採取後, 造影剂を注入しはじめて造影された。左耳介前 方と左頓部の異常血管腔は連続しており, 静脈性のうっ 
帯が認められた（写真 9). 以上の所見より静脈性血管腫 と診断され，局所麻酔後エタノール $5 \mathrm{ml}$ を異常血管腔 の中に直接注入した. エタノール注入直後から反応性浮 腫が認められたが, 痛みも軽度で全身状態に異常は認め られ:ょかった，翌日には，顔面部が腫脹したため圧迫を 行った。をた， 口腔内は煩粘膜と顎間㱀壁部に粘膜下血 腫と思われる発赤が認められた。腫脹や発赤は 4 日目よ り徐々に軽減し，10日目には完全に消退し，顔貌は左右 対称になった。エタノール注入は 1 回のみで副作用はな く, 退院後厳重な経過観察を行っているが, 1 年以上経 過した現在まで再発の傾向はなく, 知覚障害, 運動障害 もなく, 顔貌は左右対称で審美的にも大変満足のいく結 果が得られた（写真10）。

\section{考察}

血管腫の治療には従来より数多くの方法が試みられて いる.しかし，口腔顎顔面領域に発生した血管腫に対し ては機能的，審美的障害を残さないように考虑しなけれ ばならず，治療法の選択には苦虑することも多く，やむ をえず放置されている症例も多いと思われる。そこでわ れわれは, 肝細胞癌の治療法として最近注目されている $\mathrm{PEIT}^{1)}$ に着目し，口腔外科領域の血管腫治療への応用を 試みた。

エタノールは, ペインクリニックで種々の神経ブロッ クをはじめ, 内科領域でも食道静脈瘤 $\left.{ }^{2}, 3\right)$ に対し経カテ ーテル的に用いられて括り，腎細胞癌 ${ }^{4)}$ に対するェタ, 一ル塞栓術, 肝頖胞 ${ }^{5)}$ ・腎囊胞縮小術 $\left.{ }^{6}, 7\right)$ 等への応用の報 告もある. 最近では, 肝細胞癌1)に対し応用されており, 臨床面で広く用いられている，血管奇形に対しては，佐 々木 $5^{8)}$, Takebayashi $ら^{9)}$ は腎の動静脈奇形に, Yakes $ら^{(0)}$ は大腿部の動静脈奇形にエタノールを使用した症例 を報告している. 頭頸部の血管腫に対しては, Tress ら ${ }^{11)}$ は海綿状血管腫に, Berenstein ${ }^{12)}$ は上唇の静脈性血管腫 に, 本邦では Muto ら ${ }^{13)}$ により上唇の動静脈性血管腫と 毛細管性血管腫に対し, エタノール塞栓療法が報告され ている.

エタノールの作用としては，(1) 脱水，固定作用によ り腫瘍細胞を変性壊死に至らせる直接作用と, 間接作用 としての, (2) エタノールの脱水, 凝固作用により血球 成分が凝集し血栓を形成する。 (3) タンパクの变性と凝 固. (4) 動脈のスパスムと血流低下. (5) 血管の内皮細胞 の損傷による 血小板血栓の形成. (6) 血管透過性の变化 により生ずる周囲組織の浮腫と, それに伴ら循環障害な どによる阻血効果などが考えられている.

血管奇形にはいろいろな分類が試みられているが，治 療の観点からみれば，血管造影所見に基ついた血行動態 による分類が望ましいと思われる。石田 ${ }^{14)}$ の分類による と，血管奇形は動静脈瘻と血管腫の 2 つのタイプに分け
られ, 血管腫はさらに毛細血管性, 海綿状, 静脈性, 動 静脈性に分類される。これを血行動態により分類すると 動静脈血管腫, 動静脈瘻などの high-flow タイプと, 毛 細血管性, 静脈性, 海綿状血管腫などの low-flow タイ プに分類される ${ }^{15)}$.

本法の施行に当たっては high-flow タイプと low-flow タイプとで若干の差異があるので, それぞれの術式と留 意点について述べる.

\section{1. low-flow タイプ}

まず第一に処置前に血管造影を行い，血管の動態を知 ることが肝要である。動静脈性血管腫であれば，拉およ そ腫瘍の大きさを推定できるが，静脈性あるいは海綿状 血管腫では, 症例 1 や症例 2 のように血管造影ではよく 造影されないことが多い，そのような時には，直接経皮 的あるいは経粘膜的に 血管腫の中心部に注射針を刺入 し, 内容液を吸引し，次に造影剤を直接注入することに より腫瘍が描出される。これにより腫瘍の大きさを推定 し，局所麻酔下にェタノールを腫瘍の大きさの約 $50 \%$ 目安に局注する。症例によっては少量ずつ日を変えて繰 り返し局所注入する。症例 1 では腫瘍は比較的大きいに も拘らず，穿刺で少量の血液しか吸引できなかったこ と，82歳と高齢であったこと，腫瘍が口底部にあり舌根 沈下の可能性があったことなどより，エタノール注入は 1 回左右 $1 \mathrm{ml}$ ずつとし, 計 4 回の処置で完全に腫瘍は 消失した，症例 2 では $7 \mathrm{ml}$ の血液が穿刺吸引できたの で, エタノールを $5 \mathrm{~m} l$ 局所注入した。 その後, 経過を みてェタノールを追加する予定であったが 1 回の処置で 完全に腫瘍は消退した，投与間隔に定説はないが，注入 量が少ない場合でも 2 週間, 多い場合は $1 \sim 3$ か月経過 してから追加するほうが良いと思われる．静脈性や海綿 状血管腫で, はっきりした流入動脈や灌流静脈がない場 合はエタノールの注入量は少なくても効果が高いと思わ れた。

\section{2. high-flow タイプ}

動脈性血管腫は血管造影で腫瘍は明白に描写される. 流入動脈まで超選択的にカテーテルを進め, そこでェタ ノールを血液の逆流がなくなるまで，または腫瘍の大き さの30\%ぐらいまでを目安に血管内に注入する，血管内 に注入することによりェタノールは塞栓物質として作用 し, 先に述べた脱水，固定，凝固，血栓形成等の作用に より腫瘍は縮小壊死すると考えられる。症例によって は，日を変えて数回処置を繰り返す必要があることもあ る。しかし，一度主要血管がェタノールで塞栓されると 血管造影操作は不可能なことが多い。この場合, 直接腫 瘍の中心部に注射針を刺入し，内容液を吸引後，造影剂 を直接注入することにより造影できる。エタノールは大 変危険な塞栓物質であるので, 標的組織以外の損傷は最 小限にとどめなければならない，造影により腫瘍の広が り, 大きさを推定し，その病変の大きさの50\%以下の量 
のエタノールを直接局所注入する。 その後, 静脈性ある いは海綿状血管腫に対する処置と同様に行う。

\section{3. 術後処置について}

術後早期に発赤を伴う著明な浮腫が必発するが，これ は土タノールによる化学的炎症や毛細血管の破壊に伴ら 血墏成分の漏出によるものと思われる，舌や口底にエタ ノールを注入する場合は気道閉塞の危険があり, 気管切 開の準備など敩重な注意が必要である。また，偶発症と して組織壊死があげられる。標的組織以外の正常組織 に, 高濃度で多量のエタノールが漏洩すると, 部位によ っては壊死を生ずる挔それがある．顔面皮下の表在性の 血管腫や皮下に軟骨の存在する鼻部の血管腫では組織壊 死の可能性が高く慎重に対処すべきである，また，眼窩 周囲など重要臓器の近くの血管腫では漏洩に細心の注意 を払ら必要がある。しかし，Tress ら ${ }^{11)}$ の報告にあるよ らに, 眼瞼の血管腫に対しても慎重に本療法を適用する ことにより，良好な結果が得られている。エタノール注 入による痛みも考慮すべき問題である。エタノール注入 は激烈な痛みを伴うので血管造影と併せて全身麻酔下で の処置を推奨する意見もある。しかし，本報告例では局 所麻酔のみで注入でき, 術後の疼痛も軽度であった， 1 回 $5 \mathrm{ml}$ 以内の量をゆっくり注入すれば，局所麻酔下で も十分処置可能であると思われた。

適用にあたっては，患者の年齢，全身状態，血管腫の 種類, 部位, 大きさなどを十分に考慮し，1回に大量に 注入せず，経過をみながら少量ずつ複数回にわけて行う ほうが安全である，以上の注意事項を守れば本療法は口 腔顎顔面領域の，あらゆる部位に適応可能であり，きわ めて優れた治療法であると考えられた。

\section{結語}

口腔顎顔面領域の血管腫の治療には，腫瘍に対する効 果と併せて，局所の機能的，審美的な面も考慮しなけれ ばならず，治療法の選択に苦慮することも多い，今回わ れわれは，82歳女性にみられた口底の海綿状血管腫と， 64歳女性にみられた顔面の静脈性血管腫に対して, 純エ タノールの局所注入療法を行い, 機能・審美性を損らこ となく腫瘍が消失し，非常に満足のいく結果が得られ た. 本療法は口腔顎顔面領域の, ぞの部位でも適応可能 と思われ，きわめて優れた治療法であると考えられた。 純エタノールの作用機序, 本療法の術式, 留意点, 副作 用等についても検討を加え報告した.

本論文の要旨は平成 3 年 6 月 9 日，第 16 回日本口腔外 科学会中部地方会 (名古屋)に拈いてロ演発表した.

\section{引用 文 献}

1）杉浦信之，高良健司，他：超音波映像下経皮的 腫瘍内エタノール注入による小肝細胞癌の治療 䀒蔵 24: 9201983.

2) Yune, H.Y., Klatte, E.C., et al.: Absolute ethanol in thrombotherapy of bleeding esophageal varices. AJR 138: 1137-1141 1982.

3) Yune, H.Y., O'Connor, K.W., et al.: Ethanol thrombotherapy of esophageal varices; further experience. AJR 144: 1049-1053 1985.

4) Ellman, B.A., Parkhill, B.J., et al.: Ablation of renal tumors with absolute ethanol: A new technique. Radiol 141: 619-626 1981.

5) Bean, W.J. and Rodan, B.A.: Hepatic cysts: Treatment with alcohol. AJR 144: 237-241 1985.

6) Bean, W.J.: Renal cysts: Treatment with alcohol. Radiol 138: 329-331 1981.

7) 川村寿一, 目襄 勝, 他 : 経皮的腎嚷胞穿刺に よる $95 \%$ ェノール注入療法；第 2 編：臨床成 績の検討. 泌尿紀要 30:589 1984.

8）佐々木光信, 田所茂, 他 : 腎動脈奇形に対す る absolute ethanol 使用選択的血管栓塞術. 泌 尿紀要 $30: 295-2981984$.

9) Takebayashi, S., Hosaka, M., et al.: Arteriovenous Malformations of the Kidneys; Ablasion with Alcohol. AJR 150: 587-590 1988.

10) Yakes, W.F., Pevsner, P., et al.: Serial Embolizations of an Extremity Arteriovenous Malformation with Alcohol via Direct Percutaneous Puncture. AJR 146: 1038-1040 1986.

11) Tress, B.M., Wilson, J.L., et al.: Ablation of Head and Neck Cavernous Haemangiomas by Direct Alcohol Injection. J Intervent Radiol 2: 147-150 1987.

12) Berenstein, A.: Discussion for "The Treatment of Capillary-Venous Malformations Using a New Fibrosing Agent." Plast Reconstr Surg 71: 613-614 1983.

13) Muto, T., Kinehara, M., et al.: Therapeutic Embolization of Oral Hemangiomas with Absolute Ethanol. J Oral Maxillofac Surg $48: 85-881990$.

14）石田 修：動脈瘤, 血管奇形。重松 康, 星野 文彦，他；放射線医学大系。1 $16, \ldots$ 中山書店，東 京, 1986, p 76-84.

15) Akker, H.V.D., Kuiper, L., et al.: Embolization of an Arteriovenous Malformation of the mandible. J Oral Maxillofac Surg 45: 2552601987. 